\title{
Research on New Relation between the Chinese Government and Trade Associations
}

\author{
Ao Xue ${ }^{1}$, Qian Yan $^{1} \&$ Liu Lei ${ }^{1}$ \\ ${ }^{1}$ College of Economic and Management, Nanjing University of Aeronautics and Astronautic, China \\ Correspondence: Ao Xue, College of Economic and Management, Nanjing University of Aeronautics and \\ Astronautic, Nanjing 210016, China. E-mail: aoxue0715@126.com
}

Received: February 23, 2017

Accepted: March 28, 2017 Online Published: April 27, 2017

doi:10.5539/ijbm.v12n5p153

URL: https://doi.org/10.5539/ijbm.v12n5p153

\begin{abstract}
The development level of trade associations is the important indicator which is used to judge the maturity of development in a country's or region's market economy. China now is in the exploratory stage of "disconnect" between the government and trade associations, and the relation between them shall be reconstructed. This paper used the methods of literature research, norms and empirical analysis, etc. to analyze the evolution and existing problems of the relation between the government and trade associations, exploring the new type of relation after trade association disconnect from the government, in order to promote the formation of the modern trade association chamber of commerce system.
\end{abstract}

Keywords: trade association, disconnect, new relation model

\section{Introduction}

The generation of trade associations is the necessary product with the development of the market economy, and it is also an important component of market economic system. The development level of trade association is the important indicator which is used to judge the maturity of market economic development in a country or region. As a market economic country, China's trade association plays a significant role. Because China is in the transitional period, the political, economic, and social environments are complex, which leads to the difficult government management and causes that trade associations does not play its role truly. Therefore, research on the reconstruction of the relation between trade associations and the government is necessary and urgent.

Since 2012, the Party Central Committee has proposed to quicken the formation of modern social organization system of separating government and community, clarifying responsibilities, and autonomy in accordance with the law and play the role of social force in social affairs management in succession. In 2015, the Chinese government website issued General Plan of Trade Association Disconnecting from Administrative Organ. Currently, China is in the exploratory stage of "disconnect" between the government and trade associations, and the policy of "disconnect" urges the government to readjust the relation with trade associations.

Chinese theoretical research on the new type of relation between trade associations and the government is in the initial stage, and a lot of scholars are dedicated to trade associations function matching, organization structural change and other researches on micro-level. The evolution, change and existing problems of the relation between the government and trade associations is analyzed comprehensively on a macro level in this paper with the methods such as literature research and norms and empirical analysis, etc.; exploring the new type of relation after trade association disconnect from the government which provides research clues and ideas for the research.

\section{Evolution of the Position Relation between the Chinese Trade Associations and the Government}

As the subjects of three different fields, the position among trade associations, government and enterprises are changed. In the planned economy era, the traditional omnipotent government undertook everything, and enterprises and trade associations were firmly controlled by the government, and trade associations representing the industry benefit did not exist. Under the current great transition period, most of trade associations are generated in system, and trade associations are under the government's control actually. The government forcibly endows trade associations with the tasks of undertaking the government transformation change, and associations are taken as the tool for expanding the regulation scope and dispatching personnel. Currently, complying with the "separating government and community" advocated by the government means that the 
pattern of three parties shall be clear about boundaries and uncontrolled. New type of relation between trade associations and the government is constructed based on this. The fig.1. represents the position relation change among trade associations, the government, and enterprises. Among which, the size of the covered area of circle represents the degree of influence.

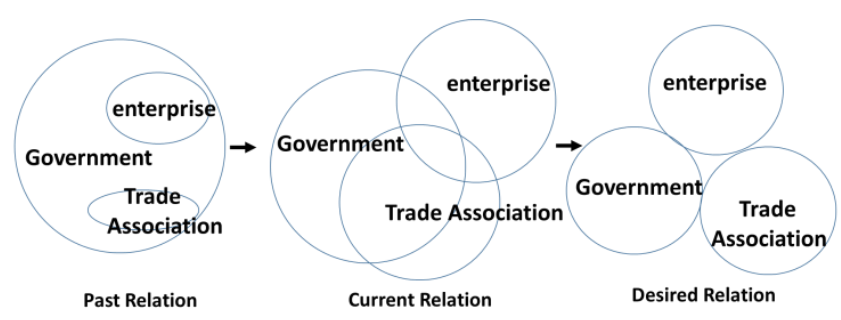

Figure 1. Evolution of the position relation of three

\section{The Problems Existed in the Current Relation and the Influence on Both Parties}

\subsection{Imperfect Management System}

So far, China has not formulated trade associations' basic law, and the management to trade association can only depend on the Registration on Management Rules of Social Organization. According to the regulations, trade association organization must have a "competent business unit". Association is mutually managed by registration department and competent business unit, and competent business unit must be the party and government department or its authorized agency; moreover, the competent business unit is endowed with the powers of the supreme. It is exactly this regulation that makes a lot of trade associations in trouble. Trade associations changed from government departments or established with government support are closely connected with the relevant administrative departments, and they tend to become the "dependency" of administrative department. The internal management lacks of democracy, and it cannot reflect member interest or provide the due interest for members.

In addition, Registration on Management Rules of Social Organization is the regulation on the general registration procedure on the whole social organization, and there is no clear instruction on the properties, functions, rights and interests, operating procedures, exist mechanism and duties of trade association. Therefore, the position on trade association is inaccurate, and it leads to insufficient legal ground for carrying out activities; consequently, the legality is difficult to be guaranteed.

\subsection{Weak Independence of Trade Associations}

Folk autonomy shall be the essential attribute of trade associations, and it shall possess the independent legal status. However, currently, some trade associations in China have the function of administrative management, and its independent operation institution has not been established. The government department regards trade association as its specialized agency.

This kind of situation mainly happens in trade associations established by the government "from top to bottom". Most associations are restructured from the original government departments or companies of industry nature, but it still keeps innumerable links with the government: it is subsidized by the government finance; there is no autonomy in personnel arrangement, and it shall accept and arrange the simplification distribution and retire personnel of the government department; it is unclear in organization relation and function orientation, and actually, it is the dependency of some government departments, performing the part of executive functions of the government.

\subsection{Insufficient Functions Playing of Trade Associations}

The most fundamental purpose for the generation of trade association is to maintain the industry benefits, while trade associations in China are the extension of the government's administrative functions. Its main role is to assist government to carry out the industry management, and consequently, the original intention of the establishment of trade association is ignored.

Trade associations established under the government's leading are existed relying on the state administrative organization, and therefore, political function of trade association is enlarged, while other functions are weak. Currently, a lot of trade associations cannot play the main function, and it is also hard to organize and coordinate 
members to carry out the collective activities. Some trade associations continued a part of function of the government, and it is very difficult to play their due functions. Some functions which are supposed to be undertaken by trade associations are mastered by the government, which makes trade associations lack of authority in function exercising process.

\subsection{Influence on Trade Associations}

Firstly, for survival and development, trade association has to struggle for the support of the government and enterprises. The government will provide fiscal subsidies; accept and arrange the simplification and distribution of personnel, acquire the government's political and fund supports through "building a good relation" with the relevant government department. In the aspect of dependence on enterprises, it mainly relies on the support of large enterprises in the industry. Because of relying on the resources and prestige come from large enterprises, these enterprise members dominate the decision-making power of trade associations, the governance principle of equal member right in non-profit organization is gone, and the interests of small and medium-sized enterprises member is damaged.

Secondly, responsibilities performed by trade associations include the service the basic functions for member enterprises, as well as public functions such as industry service, polices advocate and maintains the market order. The government divided functions of trade associations into 16, and among which, the function with public goods nature accounts for $62.5 \%$ of all functions. If trade associations want to undertake these functions endowed by the government, the government's financial support will be required. However, the main fund sources of most of trade associations in China are membership fee or donations, and the regular and institutionalized government financial aid is rare. It means that if members of trade associations need to undertake the cost of trade associations performing public functions, there will be the phenomenon of trade associations "spending the money of enterprises and working for the government".

In addition, because of insufficient legal, the trade association is congenitally deficient in resource absorbing ability and legitimacy foundation.

\subsection{Influence on the Government}

Under the current relation between the government and the community, a lot of functions which shall be undertaken by trade associations are undertaken by the government actually because the government does not delegate powers. With the rapid expansion of the responsibilities undertaken by the government, facing the growing and diversified demands of public products, the government's supply capacity will be insufficient, and the cost will be increased rapidly, thus the government's failure will be caused. Moreover, the output of public goods is monopolized by the government, and the bureaucratic style of work is bound to breed, while the government department with low efficiency is hard to keep pace with the market economic development.

The highly undeveloped of trade associations make the government administration lack of the intermediary organizations which can be authorized, in order to replace and supplement its functions effectively, and consequently, the government functions can only be transferred within its internal scope. Trade associations cannot provide the society with flexible and convenient public services, which aggravates the burden of the government undertaking the public services largely.

\section{Role Definition on the Government and Trade Associations after Reconstructing}

\subsection{Government: Indemnitor of Legal Environment}

Legal construction of administrative system and the legislation of the government's behavior are not only the requirements of the government's functions transformation, but also the requirements for the healthy development of trade associations. The lagging construction of legal system of non-governmental organizations in China and the problems of randomness administrative management restrict the development of non-governmental organizations severely.

Therefore, the development of trade associations is inseparable from a good law and system environment. The government should strengthen the legal construction of administrative system and realize the legislation of government agencies' working procedures. As the indemnitor of the development of trade association, the government relieves the unreasonable restrictions of the existing system to trade associations in the aspects of establishment, operation and function performing, and establishes the complete institutional environment which is benefit for trade associations' survival and development under the market economic condition, which makes the government and trade associations possess the independent and equal legal status, clarifying responsibilities. It is the primary task for the construction of the new type of relation between the government and trade association. 


\subsection{Government: Supporter of Trade Associations}

"The market is not ideal, and there is market failure". This is why we need the government's intervention. The government's intervention makes up the market defect to a certain degree and promotes the economic development. Therefore, the government shall also provide support for the development of trade associations, in order to reduce the risks of the full autonomy of trade associations. For examples, the government can consult trade associations for the issues of policy formulation and reform optimization; help trade associations plan the development direction of a certain trade association; guide the problems in the development process of trade associations; promote the reciprocal working relation; determine the total amount and direction of subsidies for the specific trade associations and provide subsidies; provides the site and assistance for the cause established by trade associations, etc.

Generally speaking, the government shall reduce its control and management to trade associations, while planning, guidance, coordination, exchange, service and the necessary support functions shall be enhanced. The government shall play the role of "supporter", give full consideration to the demands and desires of trade associations, support the development of trade associations, and promote both of them to form the interactive cooperative partnership.

\subsection{Government: Purchase of Public Service}

Under the market economic condition, the market mechanism shall play the decisive role in the cooperation between the government and trade associations. Service purchase is the important mode for the government equally cooperating with trade associations based on the market mechanism. In 2007, the government proposed that we shall "establish the system of the government purchasing the services of trade associations". In 2009, proposed that the government "the consignment agreement shall be signed and the corresponding costs shall be paid with the mode of service purchase". In 2013, after the government issued the Guidance about the Government Purchasing Service from Social Forces, it has been the reform trend for the government purchasing services from social organizations including trade associations.

The government purchasing service is beneficial for enhancing the autonomy and vitality of trade associations. The government purchasing service can provide trade associations with the required resource, guarantee of funds, operation support, and its development vitality can be enhanced, and consequently, its autonomy and independence are guaranteed. Secondly, the government purchasing services is beneficial for government establishing the equal partnership with trade associations based on market mechanism, which replaced the previous administrative subordination relation of trade associations on the basis of superior and subordinate. When the government purchases services, cooperation contact is established through market mechanism, and their respective rights and obligations are determined through legal contracts. Last, as the provider of functions of public goods and the undertaker of cost, the government entrusts trade associations to perform the function of public goods through the modes of the government's purchasing or fiscal subsidies, which can solve the resource allocation of trade associations and improve the efficiency of trade associations providing services.

\subsection{Associations: Responsible Person for Enhancing Self Abilities}

Insufficiency of trade associations' self-construction leads to the reliance on the government to a certain degree. Only establishing the strict self-discipline mechanism and supervision mechanism, can the government delegate executive power to trade associations and make trade associations possess the complete independence.

Trade associations shall meet the demands for its development including: 1) Scientifically establishing operating mechanism. It shall consider the scale, functions, membership requirements and other elements with its dynamic change. 2) Equip with enough people. The human element shall be rationally structured and scientifically combined in the aspects of ability, knowledge, and age, etc. 3) Formulating the complete institutional norms. Include decision-making system, member representative conference system, and financial regulation, etc. 4) Possessing the material and technical conditions, including the independent office, source of finance, and basic equipment, etc.

Therefore, trade associations shall enhance their own abilities firstly, complete their own system construction, improve service level and independent operation ability, and be responsible for their own construction.

\subsection{Associations: Autonomy Connecting the Government and Enterprises}

As the bond connecting the government and enterprises, trade associations need to constantly reflect enterprises' demands to the government, propose political suggestions, convey the government's intention to enterprises, guide enterprises to abide by current policies and decrees. It plays the important service, communication, coordination, and connection roles in the economic and social development. 
The government and enterprises are connected by trade associations with their own autonomy, authority, and service. It should keep its independent autonomy and avoiding becoming the auxiliary of any institution, and the role of the government guiding and standardizing enterprises can be effectively played.

\subsection{Associations: Undertakers of Public Functions}

Trade associations are constituted by members of one industry, because member enterprises understand the market quotation mostly. Trade associations master a lot of information and are strongly specialized, thus, it possesses a relative high authority. Under the market economic condition, the government is unable and impossible to provide all services required by enterprises. If the government performs some functions, the cost will be higher and the effect will be worse. Therefore, the government exists selectively, while trade associations enter selectively. Trade associations give full play of their own advantages and spirit of innovation, and participate in public affairs more positively.

After Evaluate and divide the government functions, the functions which are chargeable or not supposed to be undertaken by the government shall transfer to trade associations who have the ability to undertake. Trade associations shall positively participate in public affairs, and play positive roles in economic and social affairs jointly. For examples, some trade associations shall undertake some public governance functions such as industry governance and social governance; participate in and advocate public policies and setting agenda; assist the government to mutually promote the formulation and complete of public policies.

\subsection{The New Relation Model between the trade Associations and the Government}

After trade association disconnects from the government, it doesn't mean that it won't have any connection with the government anymore, but the government constructs the new type of cooperative relation with trade association based on understanding their respective responsibilities, governing the industry and the public affairs synergistically.

Therefore, as the important main body for reconstructing the relation between the government and community, the government and trade associations play different levels of roles. The responsibilities of the government mainly lay in institutional aspect and resource allocation aspect. The government provides the effective resources and equal competition through establishing the institutional environment of complete trade association survival and development. The responsibilities of trade association mainly lay in the actual operation level, adapting to demands of market and enterprises, constantly completing and expanding the services to members, participating in public affairs, and maintaining the market order. Fig. 2. represents the reconstruction model of the new relation between the government and trade association.

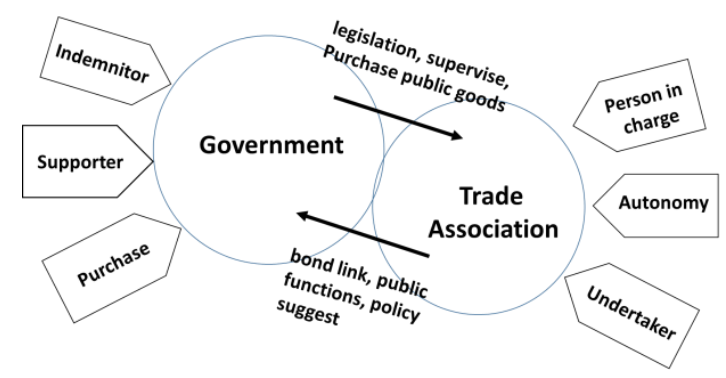

Figure 2. New relation model of the government and trade association

\section{Conclusion}

The construction of the new relation between the government and trade associations aims at creating a good external environment for the quickening formation of modern trade association system fundamentally. Currently, the relation between the government in China and trade association is in the transition stage of "destroy the old and establish the new". The new type of relation liberates trade associations from the constraint of the government, makes the government and trade association possess independent and equal legal status and clarify responsibility; on the other hand, the interests, rights and obligations relations between the government and trade association are mainly regulated through market mechanism and legal procedure, which promotes the formation of modern trade association system. 


\section{Acknowledgements}

This work was supported in part by the trade association research team. I'd like to express my sincere thanks to all those who have lent me hands in the course of my writing this paper. I'd like to show my sincere gratitude to my supervisor, Mrs. Qian, who has given me so much useful advices on my writing, and has tried her best to improve my paper. I'd also like to express my gratitude to my teammates who offered me references and information on time. Without their help, it would be much harder for me to finish my study and this paper.

\section{References}

Bradley, C. (2008). The roles of professional and trade associations. Strategic Organazation, 8(2), 59-68.

Jia, X. J. (2004). The trade association in the transformation period-role, function and management system. Beijing: Social Science Literature Publishing.

Jia, X. J., \& Zhang, J. (2016). Strategies and challenges after the trade associations disconnect from the government. Social Governance Review, 3(7), 99-105.

Lawton, R. T., \& Nelson, P. (2015). Why management researchers should pay more attention to trade associations. Publishing Research Quarterly, 13(3), 224-232.

Li, Y. (2014). The market oriented reform of trade associations. The Jurist, 15(7), 19-23.

Liu, H. X. (2014). Only legislation can give more space for the trade association construction and development after the decoupling. Tianfu New Idea, 8(2), 71-78.

Mao, N. (2013). Research on the positive interaction between trade association and government. Theory Monthly, 18(9), 32-41.

Perry, M. (2002). Trade associations: Exploring the Trans Tasman environment for business associability. Management \& Organization, 15(4), 414-422.

Qian, C.F., Zhao, J. G. (2012). The choice of the mode of relation between the trade association and the government. Economy and Management, 9(9), 55-58.

Rotfeld, H. J. (2009). Misplaced marketing: Mismanagement of misfocused trade association leaders. Consumer Marketing, 20(4), 201-202.

Song, X. Q. (2014). Beware of three risks in the process of the trade associations disconnect from the government. China Social Organization, 10(3), 32-33.

Xue, H. H. (2006). Under the background of economic globalization, the relationship between the trade association and government. Journal of Soochow University, 26(5), 65-67.

Yu, J. X. (2006). Folk chamber of Commerce and local government based on the research of Wenzhou City, Zhejiang province. Beijing: Economic Science Publishing.

Yu, J. X., Ming, F. (2004). Trade associations-between the government and enterprises, Hangzhou: People of Zhe jiang Publishing.

Zhou, J. (2015). Separation of functions is important for the trade associations disconnect from the government. China Social Organization, 11(13), 66-73.

\section{Copyrights}

Copyright for this article is retained by the author(s), with first publication rights granted to the journal.

This is an open-access article distributed under the terms and conditions of the Creative Commons Attribution license (http://creativecommons.org/licenses/by/4.0/). 